\title{
Pengaruh Penerapan Teknik Spotlight Terhadap Pemahaman KONSEP MATEMATIS SiSIWA KelaS VIII SMPN 1 BATANG ANAI PADANG PARIAMAN
}

\author{
THE EFFECT OF SPOTLIGHT TECHNIQUE IMPLEMENTATION TO UNDERSTAND \\ Mathematical Concept Students Class VIII SMPN 1 Batang ANaI PadANG \\ PARIAMAN
}

\author{
Dewi Yuliana Fitri' ${ }^{1}$ Zulfitri Aima ${ }^{2}$ dan Muhlisin ${ }^{3}$ \\ 1 Program Studi Pendidikan Matematika, STKIP PGRI SUMBAR \\ Padang, Sumatera Barat, Indonesia \\ Dewiyulianafitri2@gmail.com \\ 2,3 Program Studi Pendidikan Matematika, STKIP PGRI SUMBAR \\ Padang, Sumatera Barat, Indonesia
}

\begin{abstract}
Abstrak
Penelitian ini dilatarbelakangi oleh rendahnya pemahaman konsep matematis siswa kelas VIII SMPN 1 Batang Anai tahun pelajaran 2016/2017, siswa malu bertanya dan tidak berani mengeluarkan pendapat di dalam kelas, siswa hanya mengerti saat mendengarkan penjelasan dari guru. Penelitian ini bertujuan mengetahui apakah pemahaman konsep matematis siswa dengan menerapkan Teknik Spotlight lebih baik dari pada pemahaman konsep matematis siswa dengan pembelajaran konvensional pada kelas VIII SMPN 1 Batang Anai Padang Pariaman. Jenis penelitian adalah penelitian eksperimen, dengan rancangan penelitian random terhadap subjek. Populasi penelitian adalah semua siswa kelas VIII SMPN 1 Batang Anai tahun pelajaran 2016/2017 yang terdiri dari enam kelas. Teknik pengambilan sampel dilakukan secara acak, terpilih kelas $\mathrm{VIII}_{2}$ sebagai kelas eksperimen dan kelas $\mathrm{VIII}_{4}$ sebagai kelas kontrol. Instumen penelitian adalah tes pemahaman konsep matematis. Bentuk tes yang digunakan adalah bentuk uraian dengan reliabilitas tes 0,780 . Teknik analisis data yang digunakan adalah uji t satu pihak. Berdasarkan hasil uji hipotesis diperoleh nilai $t_{\text {hitung }}=1,833$ dan $t_{\text {tabel }}=1,67$. Hipotesis diterima karena $t_{\text {hitung }}>t_{\text {tabel, }}$, sehingga hipotesis yang diajukan diterima pada taraf nyata $\alpha=0,05$. Dapat disimpulkan bahwa pemahaman konsep matematis siswa dengan penerapan strategi spotlight lebih baik daripada pemahaman konsep matematis siswa dengan pembelajaran konvensional di kelas VIII SMPN 1 Batang Anai.

Kata Kunci: Spotlight, Pemahaman Konsep.
\end{abstract}

\begin{abstract}
This research is motivated by the lack of understanding of mathematical concepts in the VIII class at SMPN 1 Batang Anai 2016/2017 school year, students are embarrassed to ask and do not come forward and speak in the classroom, the students only understand when listening to the explanation from the teacher. This study aims to determine whether the student's understanding of mathematical concepts by applying the technique Spotlight better than on understanding mathematical concepts students with conventional learning in the VIII class at SMPN 1 Batang Anai, Padang Pariaman. This type of research is experimental research, the design of randomized
\end{abstract}


trials on the subject. The study population was all students of class VIII SMPN 1 Batang Anai 2016/2017 academic year consisting of six classes. The sampling technique is done randomly selected the VIII2 class as an experimental class and the VIII4 class as the control class. Research instrument is a test of understanding mathematical concepts. The shape of the test used is the narrative form with the reliability of the test. The data analysis technique used is the test of the party. Based on the hypothesis test results obtained by value $t=1.833$ and table $=1.67$. Accepted hypothesis for $t>t$ table, so the hypothesis is accepted at significance level $\alpha=0.05$. It can be concluded that students understanding of mathematical concepts with the application strategy better spotlight than understanding students mathematical concepts with conventional learning in the class of VIII at SMPN 1 Batang Anai.

Keyword: Spotlight, understanding of concepts.

\section{Pendahuluan}

Matematika merupakan salah satu mata pelajaran yang dipelajari mulai dari Sekolah Dasar sampai Perguruan Tinggi. Pentingnya belajar matematika tidak terlepas dari peranannya dalam kehidupan sehari-hari, yaitu sebagai penunjang IImu Pengetahuan dan Teknologi (IPTEK). Oleh karena itu, pelajaran matematika merupakan salah satu mata pelajaran wajib yang diajarkan pada setiap jenjang pendidikan, baik pada jenjang pendidikan dasar, pendidikan menengah, dan pendidikan tinggi. Seperti yang diungkapkan oleh Suherman (2003: 60)

"Matematika merupakan salah satu mata pelajaran yang diajarkan disetiap jenjang pendidikan. Selain untuk menambah ilmu pengetahuan guna mempersiapkan diri memasuki jenjang pendidikan yang lebih tinggi, matematika juga berguna untuk memecahkan masalah dalam kehidupan sehari-hari dan untuk ilmu pengetahuan lainnya. Matematika juga dapat membentuk pemikiran logis, kritis dan praktis, serta sikap positif dan jiwa kreatif".

Berdasarkan kutipan diatas, dapat disimpulkan bahwa matematika berperan penting dalam membentuk manusia yang berkualitas, karena dengan mempelajari matematika sejak dini dapat membantu siswa memecahkan masalah dalam kehidupan nyata maupun masalah dalam disiplin ilmu lainnya. Untuk itu penguasaan yang baik terhadap mata pelajaran matematika sangat diperlukan.

Keberhasilan peserta didik dalam memahami konsep matematis merupakan salah satu tugas seorang guru. Guru harus mampu menciptakan strategi pembelajaran yang tepat sehingga dapat membangkitkan semangat siswa untuk belajar. Berdasarkan observasi yang dilakukan di SMPN 1 Batang Anai Padang Pariaman pada 22-27 Agustus 2016 terlihat bahwa proses pembelajaran masih berpusat pada guru, aktivitas siswa dalam mengungkapkan ide dan bertanya masih rendah, dan siswa hanya mengerti dan memahami pelajaran saat mendengarkan penjelasan dari guru. Hal ini tampak ketika guru mengajukan pertanyaan, siswa yang berusaha untuk menjawab hanya 2 sampai 4 orang dan cenderung orang yang sama. Hasil wawancara dengan guru matematika kelas VIII SMPN 1 Batang Anai Padang Pariaman diperoleh informasi bahwa 
siswa hanya menerima apa yang disampaikan oleh guru dan tidak berani untuk mengeluarkan pendapat serta kurang percaya diri dalam menjawab pertanyaan yang diberikan, jika disuruh ke depan mengerjakan soal latihan hanya siswa yang pintar saja yang mau mengerjakan, sedangkan siswa yang lain hanya duduk diam di kursi masing-masing melihat temannya mengerjakan soal. Hasil wawancara dengan siswa, diperoleh informasi bahwa siswa menganggap mata pelajaran matematika sulit dan membosankan, banyak rumus-rumus, menakutkan dan tidak menyenangkan, serta siswa hanya mengerti saat mendengarkan penjelasan dari guru.

Teknik Spotlight dapat membantu untuk menimbulkan kepercayaan diri siswa. Siswa Spotlight diberi tanggung jawab untuk menyampaikan pengetahuan yang telah dikuasainya berdasarkan tujuan pembelajaran kepada siswa lainnya. Siswa yang berada di tempat duduk dituntut untuk memberikan pertanyaan dan respon kepada siswa spotlight. Proses pembelajaran tidak lagi monoton mendengarkan penjelasan dari guru, mencatat materi pelajaran dan mengerjakan soal latihan, tetapi akan lebih didominasi oleh tanya jawab serta melatih siswa bertanya kepada teman sebayanya untuk menanyakan materi yang kurang dipahami. Hal ini akan membuat siswa lebih mengerti tentang apa yang mereka pelajari

\section{Metode}

Penelitian ini dilaksanakan pada semester genap mulai dari tanggal 03 Januari sampai 21 Januari tahun pelajaran 2016/2017 dan tempat penelitiannya dilaksanakan di SMPN 1 Batang Anai Padang Pariaman.

Sesuai dengan masalah dan tujuan penelitian, maka jenis penelitian ini adalah penelitian eksperimen. Menurut Arikunto (2013: 9) "penelitian eksperimen adalah penelitian untuk melihat akibat dari suatu tindakan atau perlakuan". Objek dalam penelitian ini terdiri dari kelas eksperimen dan kelas kontrol. Pada kelas eksperimen menggunakan Teknik Spotlight, sedangkan pada kelas kontrol dengan pembelajaran konvensional. Rancangan penelitian yang digunakan adalah random terhadap subjek seperti yang digambarkan pada tabel berikut:

Tabel 1.

\begin{tabular}{ccc}
\multicolumn{3}{c}{ Rancangan Penelitian } \\
\hline Kelas & Perlakuan & $\begin{array}{c}\text { Tes } \\
\text { Akhir }\end{array}$ \\
\hline Eksperimen & $\mathrm{X}$ & $\mathrm{O}$ \\
\hline Kontrol & - & $\mathrm{O}$ \\
\hline
\end{tabular}

Sumber: Arikunto( 2013:126)

Keterangan:

$X$ : Perlakuan pada kelas sampel, yaitu pelaksanaan pembelajaran Teknik Spotlight.

$\mathrm{O}:$ Tes akhir

Alat pengumpulan data yang digunakan adalah tes akhir. Tes akhir yang berbentuk esai yang mengandung indikator pemahaman konsep. Untuk mengetahui kemampuan pemahaman konsep siswa 
digunakan pedoman penskoran tinggi dari pada kelas kontrol, kemudian menggunakan rubrik analitik yang simpangan baku pada kelas eksperimen berpedoman pada Iryanti (2004: 14). Soal diuji cobakan di SMP N 2 Batang Anai, yang bertujuan untuk melakukan analisis item. Menurut Arikunto (2013: 229) kriteria koefisien reliabilitas tes $\left({ }^{r_{11}}\right)$ dikonsultasikan dengan tabel product moment. Jika $r_{11}$ lebih kecil dari harga $r_{\text {tabel }}$ yang diharapkan, maka instrumen tersebut tidak reliabel. Berdasarkan hasil perhitungan reliabilitas soal uji coba, didapat $r_{11}=0,780$ dan $r_{\text {tabel }}=0,374$ sehingga $r_{11}>r_{\text {tabel }}$ berarti dapat disimpulkan bahwa soal tes telah reliabel.

\section{Hasil dan Pembahasan}

Setelah dilaksanakan tes akhir pada kedua kelas sampel, diperoleh data pemahaman konsep matematika siswa pada tabel 2.

Tabel 2.

Hasil Tes Akhir Kelas Sampel

\begin{tabular}{ccccc}
\hline \multicolumn{6}{c}{ Kelas } & $\overline{(X)}$ & $\mathbf{S}$ & $\boldsymbol{X}_{\text {maks }}$ & $\boldsymbol{X}_{\min }$ \\
\hline Eksperimen & 85,51 & 10,45 & 100 & 65,63 \\
\hline Kontrol & 78,66 & 14,56 & 98,95 & 40,63 \\
\hline
\end{tabular}

Berdasarkan Tabel 2 terlihat bahwa nilai rata-rata pada kelas eksperimen lebih 


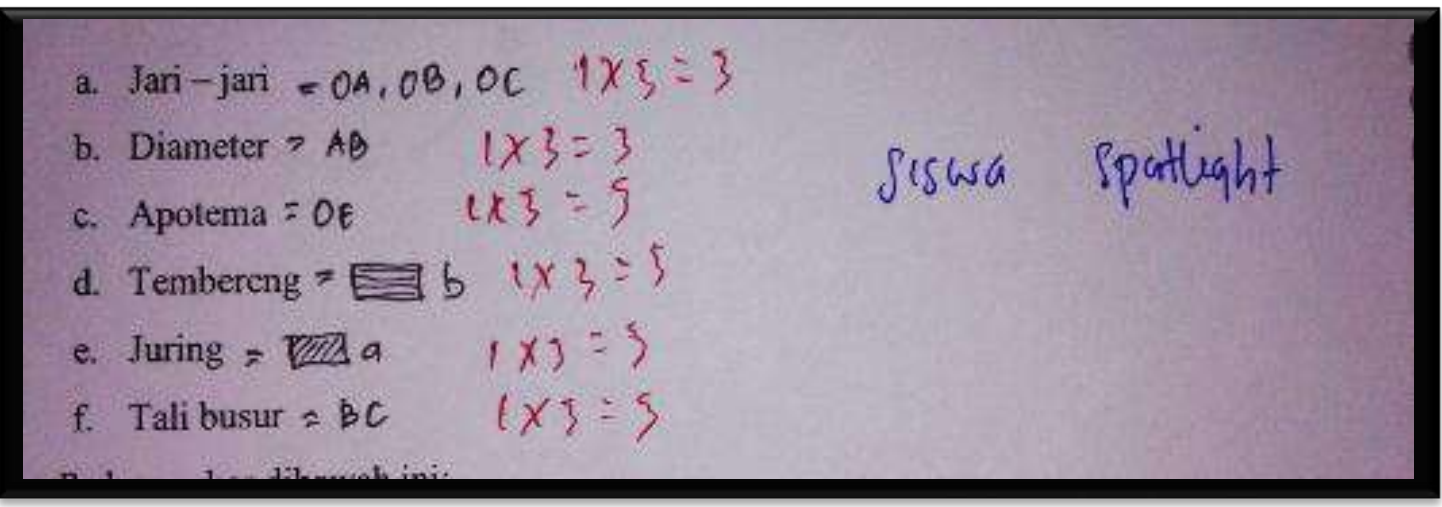

Gambar 1. Lembar jawaban siswa spotlight.

Pada pertemuan pertama ini siswa unsur dan bagian-bagian lingkaran seperti spotlight membahas materi tentang unsur- $\quad$ terlihat pada gambar 1 diatas.

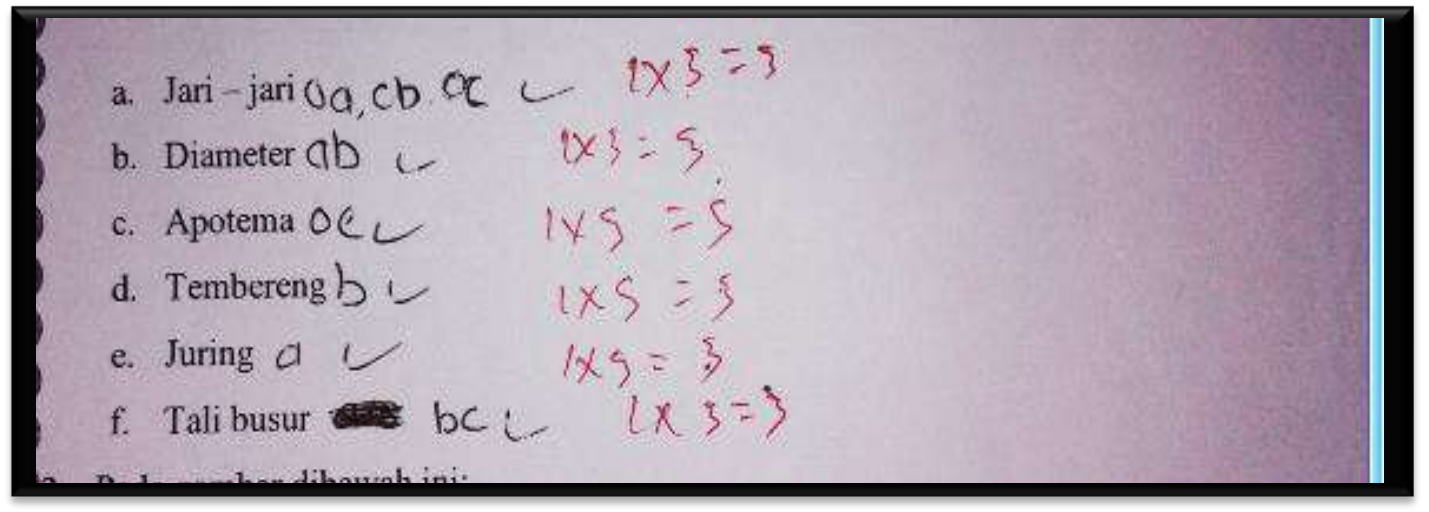

Gambar 2. Lembar jawaban siswa lainnya.

Pada pertemuan pertama ini siswa lainnya membahas pertanyaan unsurunsur dan bagian-bagian lingkaran. Siswa lainnya menjawab pertanyaan dan mengeluarkan pendapat untuk jawaban siswa spotlight, jika jawabannya sama dengan jawaban siswa spotlight maka siswa lainnya memberi tanda ceklis, jika berbeda diberi tanda silang seperti terlihat pada Gambar 2 diatas. Pada pertemuan kedua, tiga dan empat mengalamin peningkatan dikarenakan sebagian besar siswa mengangkat tangan untuk menjadi siswa spotlight. Rasa malu-malu siswa untuk tampil kedepan kelas tidak terlihat lagi, semua siswa terlihat antusias dan semangat dengan strategi spotlight ini.

Sehingga dapat disimpulkan bahwa pemahaman konsep matematis siswa yang menerapkan pembelajaran dengan strategi Spotlight lebih baik daripada pemahaman konsep matematis siswa yang menerapkan pembelajaran konvensional di kelas VIII SMPN 1 Batang Anai Padang Pariaman. Berdasarkan hasil analisis data dan pengujian hipotesis diketahui bahwa 
pemahaman konsep siswa kelas eksperimen lebih baik dari pada kelas kontrol. Ini menunjukan teknik Spotlight memiliki dampak positif terhadap pemahaman konsep matematika siswa. Lebih baiknya pemahaman konsep matematika siswa dikelas eksperimen disebabkan karena siswa termotivsi untuk memperhatikan penjelasan guru. Siswa bersemangat menjadi siswa spotlight dan siswa bersemangat untuk memberikan respon kepada siswa spotlight sesuai dengan kartu respon yang mereka angkat. Siswa lebih berani mengeluarkan pendapatnya. Selanjutnya dengan pertayaan-pertayaan yang diberikan guru kepada siswa spotlight bisa meningkatkan pemahaman konsep matematika siswa menjadi lebih baik. Hal ini terlihat dari jawaban siswa pada tes akhir yang diberikan pada kedua kelas sampel. Berikut ini adalah gambaran tes akhir untuk kedua kelas sampel.

Pada soal no 1: Tentukan unsur-unsur pada lingkaran dibawah ini

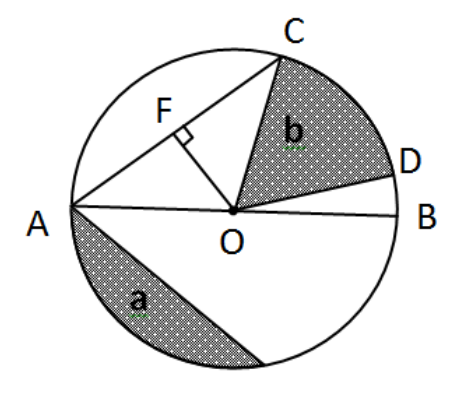

$\mathrm{E}$

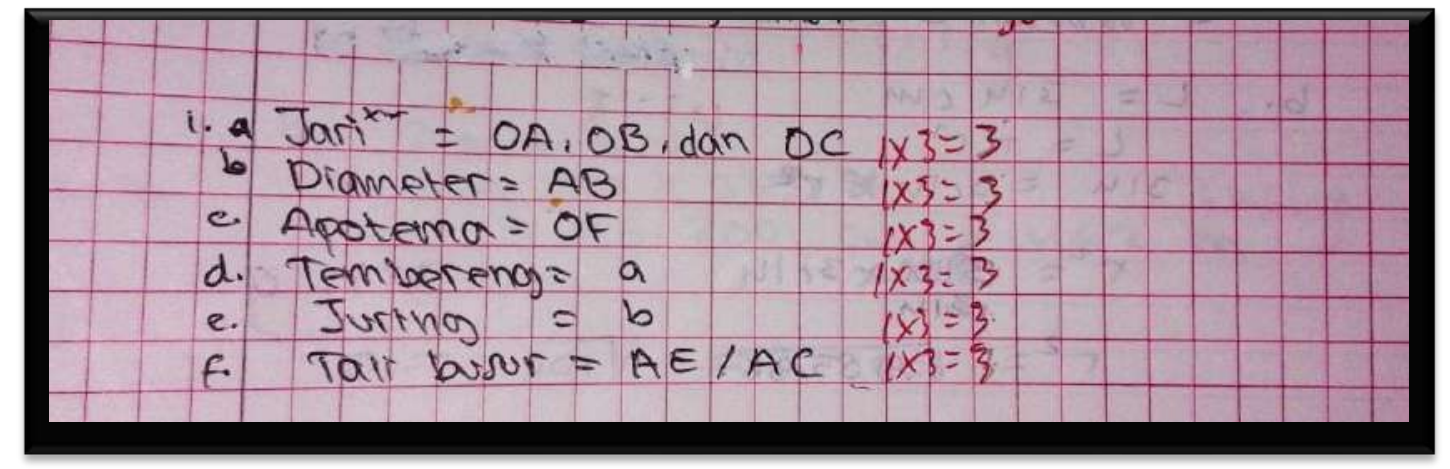

Gambar 3. Lembar jawaban kelas eksperimen.

Berdasar jawaban siswa pada kelas eksperimen terlihat bahwa siswa sudah mampu dalam memenuhi soal dengan indikator mengklafikasi objek menurut sifat-sifat tertentu sesuai dengan konsepnya, yaitu siswa dapat menentukan objek-objek menurut sifat-sifat tertentu sesuai dengan konsep yang telah dipelajari.

\section{Penutup}

Berdasarkan hasil analisis data dan pembahasan maka dapat disimpulkan bahwa pemahaman konsep matematis siswa dengan menerapkan strategi spotlight lebih baik daripada pemahaman konsep matematis siswa dengan penerapan pembelajaran konvensional di SMPN 1 Batang Anai Tahun Pelajaran 2016/2017. 


\section{UCAPAN TERIMA KASIH}

Selama pelaksanaan penelitian dan penyusunan artikel ini, penulis banyak mendapat bantuan dan bimbingan dari berbagai pihak. Pada kesempatan ini penulis mengucapkan terima kasih yang setulusnya pada: 1) Ibu Zulfitri Aima, M.Pd, selaku Pembimbing I; dan 2) Ibu Dewi Yuliana Fitri, S.Si, M.Pd, selaku Pembimbing $I I$.

\section{Daftar Pustaka}

Arikunto, Suharsimi. (2013). Dasar-Dasar Evaluasi Pendidikan. Jakarta: Bumi Aksara.
Arikunto, Suharsimi. (2013). Prosedur Penelitian Suatu Pendekatan Praktik. Jakarta: Rineka Cipta.

Depdiknas (2007). Kamus Besar Bahasa Indonesia. Jakarta : PT Index.

Ginnis, Paul. 2000. Trik dan taktik Mengajar. Jakarta : PT Index Iryanti, Puji. (2004). Penilaian Untuk Kerja.Yogyakarta : Depdiknas.

Rani Andela Siska. (2012). Penerapan Teknik Spotlight Terhadap Pemahaman Konsep Matematis Siswa Kelas IX SMP N 1 GUNUNG TALANG. Skripsi tidak diterbitkan. Padang: STKIP PGRI Sumatera Barat. 
This page is intentionally left blank 